\title{
Improved Strength-Ductility of Ti-6Al-4V Casting Alloys with Trace Addition of $\mathrm{TiC}_{-} \mathrm{TiB}_{2}$ Nanoparticles
}

\author{
Yunlong Zhu ${ }^{1,2}$, Qinglong Zhao ${ }^{1,2, *} \mathbb{C}$, Xiao Liu ${ }^{1,2}$, Run Geng ${ }^{1,2}$, Bao Wang ${ }^{1,2}$ and \\ Qichuan Jiang 1,2,* \\ 1 State Key Laboratory of Automotive Simulation and Control, Jilin University, Changchun 130025, China; \\ yunlong18@mails.jlu.edu.cn (Y.Z.); xiaoliu19@mails.jlu.edu.cn (X.L.); gengrun18@mails.jlu.edu.cn (R.G.); \\ wangbao18@mails.jlu.edu.cn (B.W.) \\ 2 Key Laboratory of Automobile Materials, Ministry of Education and School of Materials Science and \\ Engineering, Jilin University, No. 5988 Renmin Street, Changchun 130025, China \\ * $\quad$ Correspondence: zhaoqinglong@jlu.edu.cn (Q.Z.); jqc@jlu.edu.cn (Q.J.)
}

Received: 21 October 2020; Accepted: 19 November 2020; Published: 24 November 2020

\begin{abstract}
In this work, a high strength-ductility Ti64 cast alloy, containing trace $\mathrm{TiC}^{-\mathrm{TiB}_{2}}$ nanoparticles, was fabricated by adding dual-phased nano-TiC- $\mathrm{TiB}_{2} / \mathrm{Al}$ master alloys to the molten Ti64 alloys. The trace addition of the $\mathrm{TiC}-\mathrm{TiB}_{2}$ nanoparticles $(0.1 \mathrm{wt} \%)$ simultaneously reduced the size of the $\beta$ grains, the $\alpha$ laths, and the $\alpha$ colony size of the lamellar structure during casting and suppressed the coarsening of the $\alpha$ laths during heat treatment. The yield strength and the uniform elongation

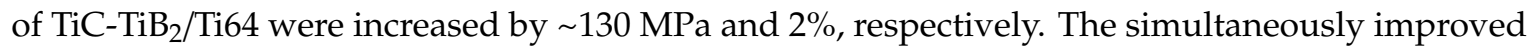
strength and ductility of the $\mathrm{TiC}_{-} \mathrm{TiB}_{2} / \mathrm{Ti} 64$ were attributed to the decrease in the $\alpha$ colony size of the lamellar structure, the significant refinement of the grains and $\alpha$ laths, and the pinning effect of nanoparticles.
\end{abstract}

Keywords: nanoparticles; nano-alloy; casting; titanium alloys; mechanical properties; grain refining

\section{Introduction}

Titanium alloys exhibit high specific strength and stiffness, excellent corrosion resistance, and good biocompatibility, and they have been widely used in many fields, such as aerospace [1], automobile [2], biomedicine [3], and offshore industries. The most extensively used titanium alloy is Ti-6Al-4V (Ti64), accounting for roughly half of the total usage of commercial titanium alloys [4]. Ti-6Al-4V is a typical $\alpha+\beta$ titanium alloy, which can obtain various microstructures through different heat treatments, thus achieving diverse mechanical properties [5].

Over the past few decades, ceramic particles such as $\mathrm{TiC}$ [6,7], $\mathrm{TiB}$ [8], $\mathrm{SiC}[9,10], \mathrm{ZrN}$ [11], $\mathrm{TiN}$ [12] have been used to reinforce titanium alloys. Among these particles, $\mathrm{TiC}$ and $\mathrm{TiB}$ [12-18] are widely used as reinforcements in the composites because of their high modulus, their excellent thermal stability, their similar density with titanium, their low lattice mismatch and thermal expansion coefficient with titanium, and their clean interface without any unfavorable reaction between particles and the titanium matrix. Many studies have confirmed that the grain and the $\alpha$-Ti lath colony of the titanium alloy were refined, and the mechanical properties were improved by adding $\mathrm{TiB}, \mathrm{TiC}$, or both [16,19-21]. Patil et al. [22] prepared TiB-reinforced Ti64 alloys with direct metal laser sintering and concluded that the martensitic laths were effectively refined with the addition of TiB and that the hardness and wear performance were improved. H.K.S. Rahoma et al. [19] prepared titanium alloy reinforced with $2.2 \mathrm{vol} \%$ micron-sized TiC-TiB particles, indicating that the strength was improved and that the grains were obviously refined. Ti alloys reinforced by micron-sized TiC-TiB particles have been reported in many articles [19-21]. The reinforced particles reported in the literature are 
mostly micron-sized [12-21]. Nano-sized reinforced particles have been proven to have a stronger strengthening effect than micron-sized particles in the powder metallurgy of Ti-base composites [23]. Recent studies on additive manufacturing of Ti alloys reported that nano-sized particles not only refined the grains and the $\alpha$-Ti lath colony but also increased the mechanical properties by pinning dislocation [24-26].

Researchers fabricated ceramic particle-reinforced titanium alloy by Spark Plasma Sintering (SPS), additive manufacturing, forging and rolling, and hot isostatic pressing. The high cost of thermomechanical processing or additive manufacturing has stimulated the continuous effort to develop and improve the casting methods for titanium alloys [27]. Investment-cast titanium alloys, which can meet the stringent requirements for structural components and better utilize available metal or reduce the cost of machining or forming complex parts, are increasingly being recognized as affordable solutions. The mechanical properties of cast Ti alloys are lower than those of the Ti alloys prepared by forging and rolling, powder metallurgy, and hot isostatic pressing. The enhancement of the cast titanium alloys via the addition of nanoparticles is a promising method, which can ensure the dimensional accuracy of the workpiece. However, the influence of nanoparticles on cast titanium alloys has been rarely reported.

In summary, extensive works have been conducted on micron and high weight ratio particle-reinforced Ti64, but few have examined trace nanoparticle-reinforced cast Ti64. In this study, the $\mathrm{TiC}-\mathrm{TiB}_{2} / \mathrm{Ti} 64$ was fabricated by adding dual-phased $\mathrm{TiC}-\mathrm{TiB}_{2} / \mathrm{Al}$ master alloys to the molten Ti64 alloys. The effects of dual-phased nanoparticles $(0.1 \mathrm{wt} \%)$ on the microstructure and tensile properties of the $\mathrm{TiC}_{-} \mathrm{TiB}_{2} / \mathrm{Ti} 64$ were investigated, and the related mechanisms were discussed. This study provides a novel method for improving the mechanical properties of Ti cast alloys for industrial production.

\section{Materials and Methods}

The raw Ti64 (Ti-6.1Al-4.0V, in wt\%) alloy billets were provided by Western Superconducting Technologies Co. Ltd. (Xi'an, China). The $0.1 \mathrm{wt} \% \mathrm{TiC}-\mathrm{TiB}_{2} / \mathrm{Ti} 64$ alloy was prepared by adding nano-TiC- $\mathrm{TiB}_{2} / \mathrm{Al}$ master alloys to the melted Ti64 alloy at $1973 \mathrm{~K}$ in a vacuum induction furnace. The melt was held for three minutes and then poured into a graphite mold. The $30 \mathrm{wt} \%$ nano- $\mathrm{TiB}_{2}-\mathrm{TiC} / \mathrm{Al}$ alloy was prepared by combustion synthesis of 70Al-21.7Ti-8.3nano- $\mathrm{B}_{4} \mathrm{C}$ powder system (in $\mathrm{wt} \%$ ), which has been described in [28]. The molar ratio of $\mathrm{TiB}_{2}$ to $\mathrm{TiC}$ was 2:1. The average diameters of $\mathrm{TiC}$ and $\mathrm{TiB}_{2}$ were 88 and $280 \mathrm{~nm}$, respectively (Figure S1). The heat treatment (duplex anneal) involved solution treatment (S) at $1193 \mathrm{~K}$ for one hour in a vacuum, then air cooling and aging (A) at $823 \mathrm{~K}$ for four hours.

The microstructure was characterized using the optical microscope (OM), a scanning electron microscope (SEM, vega3 XMU Tescan, CZ), and a transmission electron microscope (TEM, JEM-2100F JEOL, Japan). The specimens for SEM and OM observation were polished and etched in Keller's reagent $\left(3 \mathrm{~mL} \mathrm{HF}, 6 \mathrm{~mL} \mathrm{HNO}_{3}, 91 \mathrm{~mL} \mathrm{H}_{2} \mathrm{O}\right)$ for $30 \mathrm{~s}$ at room temperature. The specimens for TEM observation were ground to the thickness of $25 \sim 30 \mu \mathrm{m}$ and then thinned by an ion beam thinner (RES101). Tensile samples with a cross-section of $4.5 \times 1.5 \mathrm{~mm}$ and a gauge length of $10 \mathrm{~mm}$ were used for the tensile test. The tensile tests were carried out at room temperature using the MTS-810 testing machine at a constant ramp speed of $0.5 \mathrm{~mm} / \mathrm{min}$. Each measurement was repeated four times for each alloy.

\section{Results}

There is no apparent change in the grain size of as-cast samples and the samples after heat

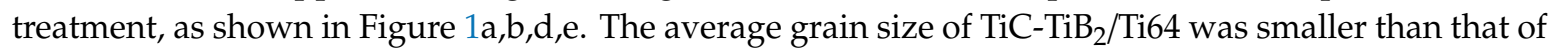
Ti64. The grain refinement of Ti64 by adding trace nano-TiC-TiB 2 particles was significant (Figure 1c,f). 

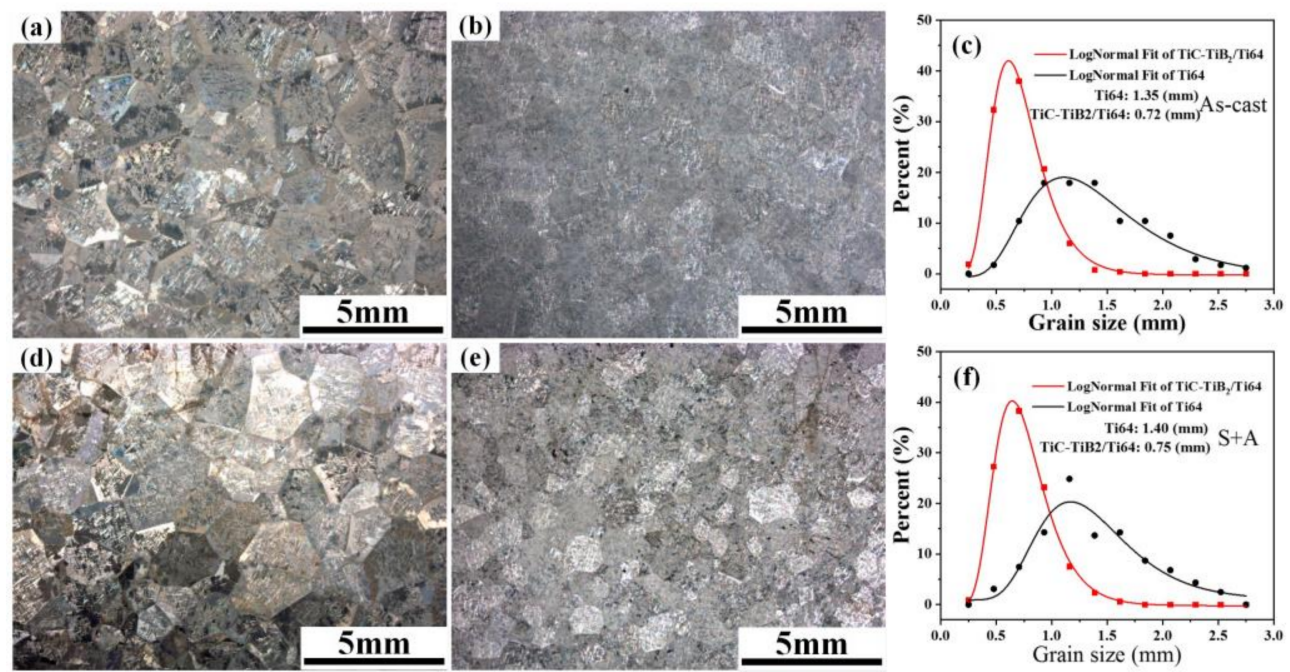

Figure 1. Metallography of Ti64 and TiC-TiB $2 / T i 64$. (a) As-cast Ti64. (b) TiC-TiB $2 / T i 64$. (c) The statistical results of the grain size of as-cast samples. (d) Ti64 after heat treatment. (e) TiC-TiB $/$ Ti64 after heat treatment. (f) The statistical results of the grain size after heat treatment.

After heat treatment, the size of $\alpha$ colony did not change significantly, as shown in Figure 2a,b,d,e. The $\alpha$ laths of the as-cast $\mathrm{TiC}^{-T i B_{2}} / \mathrm{Ti} 64$ show a basket weave structure in Figure $2 \mathrm{~d}-\mathrm{f}$. The $\alpha$ colony size of the lamellar structure in Ti64 is larger than that in $\mathrm{TiC}^{-T i B} \mathrm{~B}_{2} / \mathrm{Ti} 64$ (Figure 2c,f). After heat treatment, the width of the laths in Ti64 $(3.91 \mu \mathrm{m})$ is wider than that in the TiC-TiB $/$ Ti64 $(2.11 \mu \mathrm{m})$, as show in Figure 3c,f,i. Figure 3 suggests that adding trace nano-TiC-TiB 2 particles to the Ti64 alloys can effectually retard the coarsening of the $\alpha$ laths during heat treatment. The widths of $\alpha$-Ti and $\beta$-Ti in $\mathrm{TiC}_{-} \mathrm{TiB}_{2} / \mathrm{Ti} 64$ are thinner than those in Ti64 (Figure $4 \mathrm{a}, \mathrm{b}$ ). Figure $4 \mathrm{c}-\mathrm{f}$ shows that the particles are located in the $\alpha$-Ti, close to the boundary of $\alpha$-Ti/ $\beta$-Ti. Some particles are located inside the $\alpha$-Ti laths, as shown in Figures S2 and S3. The (200) crystal plane of the TiC is parallel to the (200) crystal plane of $\alpha$-Ti (Figure $4 \mathrm{c}$ ). The (100) crystal plane of $\mathrm{TiB}_{2}$ is parallel to the (100) crystal plane of $\alpha$-Ti (Figure $4 \mathrm{~d}$ ).
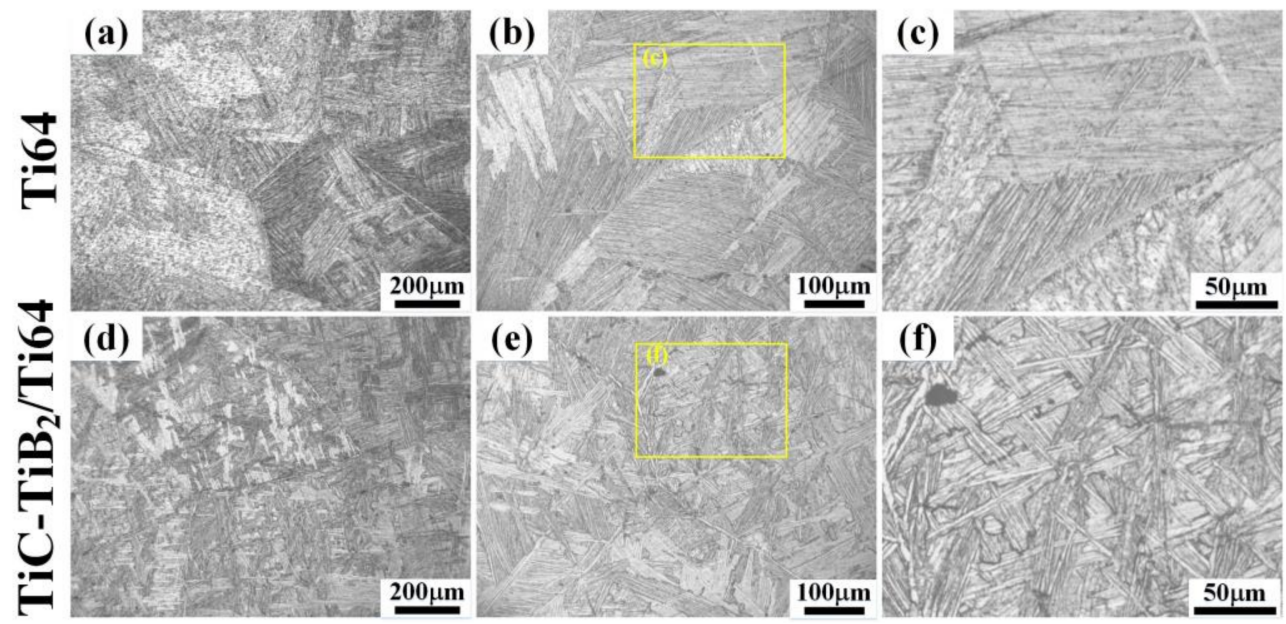

Figure 2. (a) Metallography of Ti64. (b,c) Metallographies of Ti64 after heat treatment. (d) Metallographies of $\mathrm{TiC}_{-} \mathrm{TiB}_{2} / \mathrm{Ti64}$. (e,f) Metallographies of $\mathrm{TiC}-\mathrm{TiB}_{2} / \mathrm{Ti64}$ after heat treatment. 


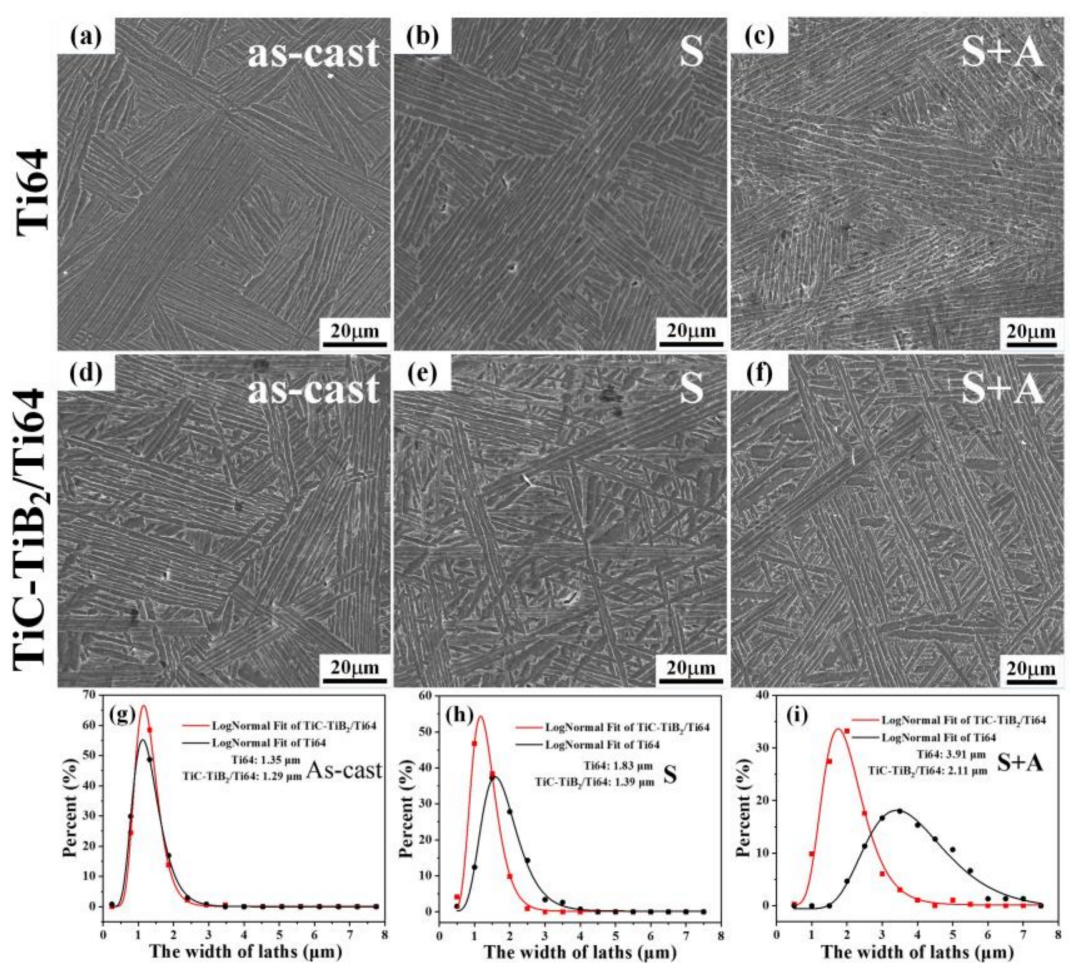

Figure 3. Microstructure analysis of the samples. (a-c) SEM images of Ti64. (d-f) SEM images of $\mathrm{TiC}-\mathrm{TiB}_{2} / \mathrm{Ti64}$. (g-i) The corresponding statistical results of the width of the laths (S: solution treatment; $\mathrm{S}+\mathrm{A}$ : solution and aging treatment).
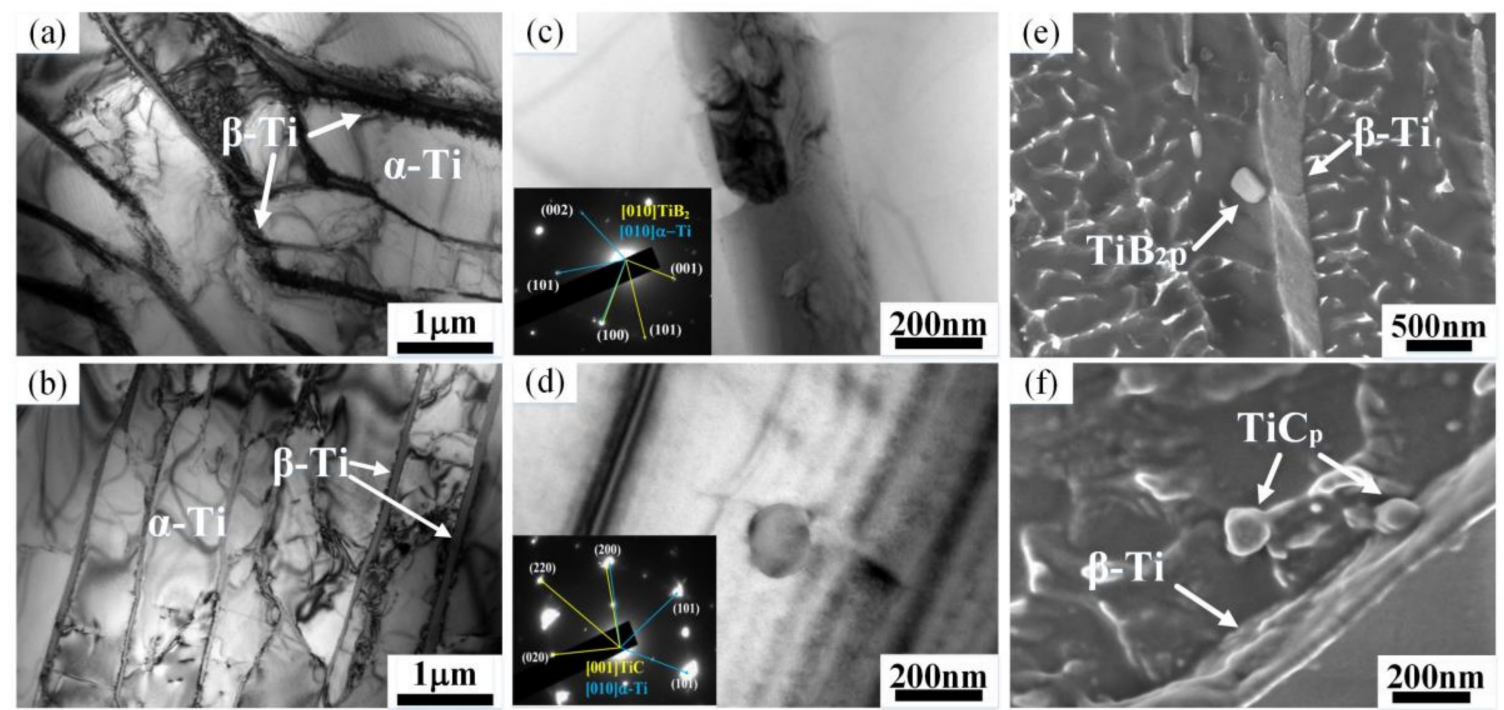

Figure 4. TEM images analysis of Ti64 and TiC-TiB $2 / T i 64$ after heat treatment. $(\mathbf{a}, \mathbf{b})$ TEM images of Ti64 and $\mathrm{TiC}_{-} \mathrm{TiB}_{2} / \mathrm{Ti} 64$. (c,d) TEM images of $\mathrm{TiB}_{2}$ and $\mathrm{TiC}$ particles in $\mathrm{TiC}-\mathrm{TiB}_{2} / \mathrm{Ti} 64$ and their SAED patterns. (e,f) FESEM images of $\mathrm{TiC}$ and $\mathrm{TiB}_{2}$.

The engineering tensile stress-strain curves of Ti64 and TiC-TiB $2 /$ Ti64 after heat treatment (Figure 5) suggest that the $\mathrm{TiC}_{-} \mathrm{TiB}_{2}$ nanoparticles improve the tensile properties; the yield strength, the ultimate

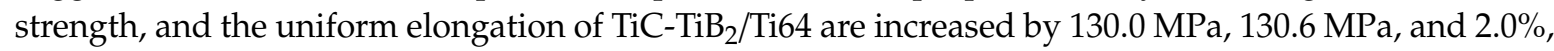
respectively. We make present the details of the tensile tests in Figure S4 and Table S1. 


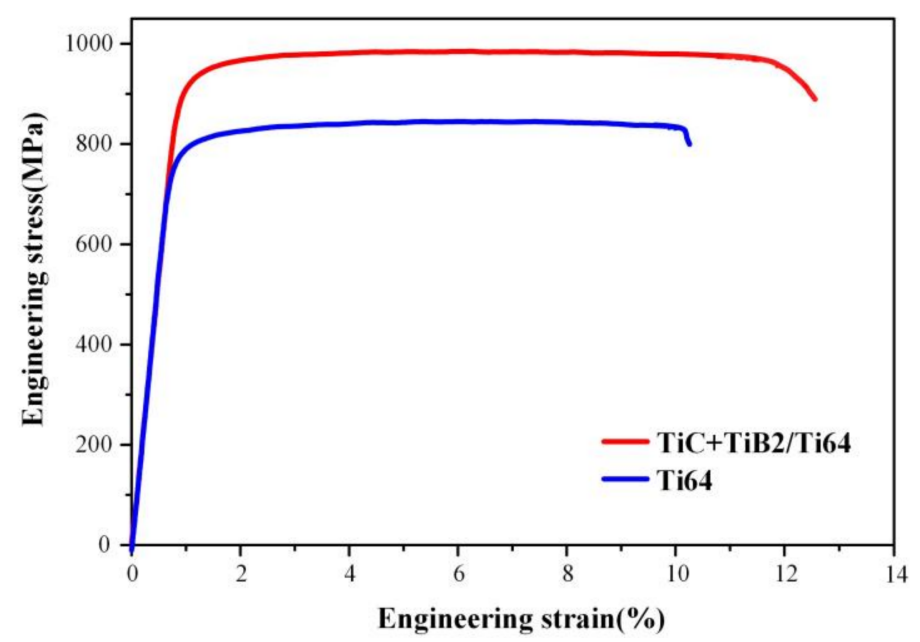

Figure 5. The engineering tensile stress-strain curves of $\mathrm{Ti} 64$ and $\mathrm{TiC}-\mathrm{TiB}_{2} / \mathrm{Ti} 64$ after heat treatment.

\section{Discussion}

In the present work, $\mathrm{TiB}_{2}$ existed instead of $\mathrm{TiB}$, which was thermodynamically favored in $\mathrm{Ti}$ alloys containing trace addition of $\mathrm{B}$. The theoretical value of $\mathrm{B}$ content in $\mathrm{TiC}-\mathrm{TiB}_{2} / \mathrm{Ti} 64$ is $0.026 \mathrm{wt} \%$, which was calculated based on the nominal amount of $\mathrm{TiB}_{2}$. According to the Ti-B phase diagram [29], this value is within the maximum solubility of $B$ in the Ti matrix. When the holding time is long enough, the $\mathrm{TiB}_{2}$ particles are expected to dissolve into the Ti matrix at high temperatures. We found $\mathrm{TiB}_{2}$ particles in the Ti64 matrix, as shown in Figure 4c,e. Thus, we believe that the undissolved $\mathrm{TiB}_{2}$ particles in the $\mathrm{TiC}_{-} \mathrm{TiB}_{2} / \mathrm{Ti} 64$ may be due to the short holding time prior to casting.

The addition of $\mathrm{TiC}^{-\mathrm{TiB}_{2}}$ induced grain refinement in Ti64 (Figure 1). Table 1 shows that the Bramfitt two-dimensional lattice mismatch between particles and $\beta$-Ti is less than $12 \%$, indicating that the $\mathrm{TiC}$ and $\mathrm{TiB}_{2}$ particles could act as heterogeneous nucleation sites for the $\beta$-Ti grains. The $\mathrm{TiC} / \mathrm{TiB}_{2}$ nanoparticles in front of the solid-liquid interface might hinder the growth of $\beta$-Ti grain during solidification [30]. The grain of Ti64 is refined by adding $\mathrm{TiC}^{-\mathrm{TiB}_{2}}$ nanoparticles. The $\mathrm{V}$ solutes increase the stability of $\beta$-Ti. The enrichment of the $\mathrm{V}$ element adjacent to the $\beta$-Ti grain boundaries is ascribed to the solute partition during non-equilibrium solidification (Figure S5). Gil et al. found that the Al content gradually decreases from the center of the $\alpha$ lath to the $\beta$ phase, while the $V$ content increases along the same direction in the as-cast Ti64 [31]. The $\alpha$ phase is first precipitated along the $\beta$ grain boundaries, rather than inside the grains [32]. The heat treatment induced homogenization and reduced the $\mathrm{V}$ content at the grain boundaries, promoting the nucleation of $\alpha$-Ti during the $\beta$-Ti $\rightarrow \alpha$-Ti phase transformation at the grain boundaries. The nanoparticles refined the grains. Therefore, the nucleations of $\alpha$-Ti increase; thus, the size of the $\alpha$-Ti colony and the width of the $\alpha$-Ti lath decrease.

Table 1. The two-dimensional lattice mismatch between $\mathrm{TiC}^{-\mathrm{TiB}_{2}}$ particles and Ti matrix.

\begin{tabular}{cccccc}
\hline Orientation & $\mathbf{( 1 0 0 )}_{\mathrm{TiB} 2} / /(\mathbf{1 0 0})_{\beta-\mathrm{Ti}}$ & $\mathbf{( 2 0 0 )}_{\mathrm{TiC}} / /(\mathbf{1 0 0})_{\beta-\mathrm{Ti}}$ & $\mathbf{( 1 0 0 )}_{\mathrm{TiC}} / /(\mathbf{1 1 0})_{\beta-\mathrm{Ti}}$ & $\mathbf{( 2 0 0}_{\mathrm{TiC}} / /(\mathbf{2 0 0})_{\alpha-\mathrm{Ti}}$ & $\mathbf{( 0 0 1}_{\mathrm{TiB} 2} / /(\mathbf{0 0 1})_{\alpha-\mathrm{Ti}}$ \\
\hline Mismatch & $5.83 \%$ & $1.57 \%$ & $9.3 \%$ & $7.06 \%$ & $2.6 \%$ \\
\hline
\end{tabular}

Shibayan Roy found that the oxygen content around the TiB particles is higher than the oxygen content at the grain boundaries due to the $\mathrm{TiB}$ interiors from the $\beta$ grain boundaries having a high propensity of grain boundary diffusion [33]. Z. Q. Chen proved that $\mathrm{Ti}_{2} \mathrm{C}$ particles have a similar effect [34]. Hence, we speculate that $\mathrm{TiC}$ and $\mathrm{TiB}_{2}$ nanoparticles also imbibe oxygen from the $\beta$ grain boundaries. O element is a strong stabilizer of $\alpha$-Ti. In addition, the lattice mismatch between $\mathrm{TiC} / \mathrm{TiB}_{2}$ and $\alpha$-Ti is less than $12 \%$ (Table 1). Therefore, the $\alpha$-Ti nucleates at the location of particles with high oxygen content. The nucleation sites of the $\alpha$-Ti increase. The size of the $\alpha$-Ti colony and the width of the $\alpha$ lath decrease. Besides, $\mathrm{TiC}^{-\mathrm{TiB}_{2}}$ particles might hinder the movement of $\alpha$-Ti boundaries. 


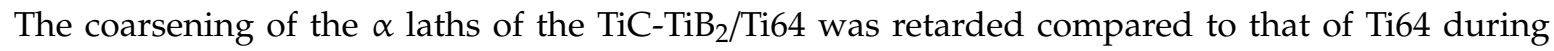
heat treatment.

The mechanical properties of Ti64 with a fully lamellar microstructure are determined by the $\alpha$ colony size of the lamellar structure and the size of the $\alpha$ laths [35]. The simultaneously increased strength and ductility (Figure 4), by adding $\mathrm{TiC}^{-\mathrm{TiB}_{2}}$ particles, are attributed to the decrease in the $\alpha$ colony size of the lamellar structure (the size of the $\alpha$ colony, as shown in Figure S6), the refinement of the $\alpha$ laths, and the pinning effect of nanoparticles on dislocations in the matrix. It has been suggested that the $\alpha / \beta$ interfaces are similar to grain boundaries and that the Hall-Petch strengthening depends on the $\alpha$ lamellar thickness [36]. According to the classic Hall-Petch equation, the strength increment is expressed as:

$$
\Delta \sigma_{H-P}=K_{y}\left(d_{y}^{-0.5}-d_{0}{ }^{-0.5}\right)
$$

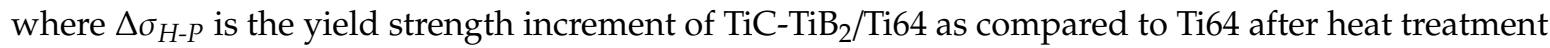
because of the refinement of the martensitic laths; $K_{\mathrm{y}}$ is the strengthening coefficient with a value of $320 \mathrm{MPa} \cdot \mu \mathrm{m}^{1 / 2}[37,38] . d_{y}$ and $d_{0}$ are the average widths of the $\alpha$ laths in the TiC-TiB $2 / \mathrm{Ti}^{2} 4$ and Ti64 after heat treatment, respectively. The calculated yield strength increment is $58.4 \mathrm{MPa}$.

Jiang et al. [39] have reported that micron-sized $(>1 \mu \mathrm{m})$ particles have a significant effect on the load-bearing strengthening of the composites, while nano-sized $(<0.1 \mu \mathrm{m})$ and submicron-sized $(0.1-1 \mu \mathrm{m})$ particles increase the strength mainly via the Orowan mechanism. The strengthening of nano-TiC- $\mathrm{TiB}_{2}$ particles can be calculated by the Orowan-Ashby equation as follows:

$$
\Delta \sigma_{O-A}=0.81 M G b(2 \pi \lambda)^{-1} \cdot \ln r / b
$$

where $\Delta \sigma_{O-A}$ is the strengthening effect caused by Orowan stress of particles; $M$ is the Taylor factor, for Ti64 alloy with a value of 3.06 [40]; $b$ is the Burgers vector of the matrix $(0.295 \mathrm{~nm})$ [41]; $G$ is the shear modulus of Ti64 matrix, with a value of $46 \mathrm{GPa}$ [42]; $r$ is the radius of particles; $\lambda$ can be calculated as follows:

$$
\lambda=0.4 d\left[\left(\pi / f_{v}\right)^{0.5}-2\right]
$$

where $f_{v}$ and $d$ are the volume fraction and diameter of particles. The calculated yield strength increment is around $16.9 \mathrm{MPa}$. The $\alpha$ colony size of the lamellar structure also strongly affects the strength, but the contribution could not be estimated due to the lack of relevant data. The increased

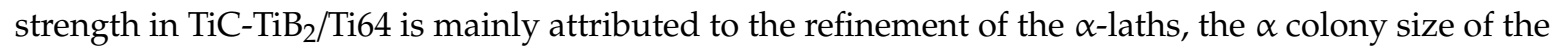
lamellar structure, and the Orowan strengthening effect of nanoparticles.

\section{Conclusions}

Adding trace $\mathrm{TiC}^{-} \mathrm{TiB}_{2}$ nanoparticles $(0.1 \mathrm{wt} \%)$ via $\mathrm{TiC}-\mathrm{TiB}_{2} / \mathrm{Al}$ master alloys to Ti64 melt during casting resulted in grain refinement (by $\sim 50 \%$ ). The $\mathrm{TiC}^{-} \mathrm{TiB}_{2}$ particles might have acted as nucleation sites for $\beta$-Ti and hindered the movement of the $\beta$-Ti grain boundary. The $\mathrm{TiC}^{-\mathrm{TiB}_{2}}$ nanoparticles decreased the width of the $\alpha$ laths and the size of the $\alpha$ colony, which was facilitated by the increased nucleation sites provided by the increase in grain boundaries and $\mathrm{TiC}_{-} \mathrm{TiB}_{2}$ nanoparticles. The $\mathrm{TiC}-\mathrm{TiB}_{2}$ nanoparticles also suppressed the coarsening of the $\alpha$ laths during heat treatment. The yield strength and the uniform elongation of Ti64 alloys were increased by $\mathrm{TiC}_{-} \mathrm{TiB}_{2}$ from 793.3 to $923.6 \mathrm{MPa}$ and from 9.2 to $11.1 \%$, respectively. This study provides a novel method for strengthening cast titanium alloys which is potentially applicable in the industrial manufacturing of particle-strengthened cast titanium alloys.

Supplementary Materials: The following are available online at http://www.mdpi.com/2079-4991/10/12/2330/s1, Figure S1. The FESEM images of $\mathrm{TiC}_{-} \mathrm{TiB}_{2}$ particles $(\mathrm{a}, \mathrm{b})$ and the statistical results of the diameter of the $\mathrm{TiC}$ and

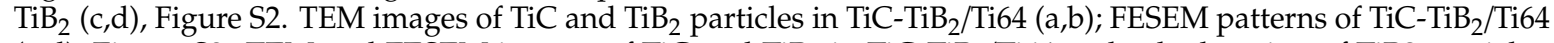
$(\mathrm{c}, \mathrm{d})$, Figure S3. TEM and FESEM images of $\mathrm{TiC}^{2}$ and $\mathrm{TiB}_{2}$ in $\mathrm{TiC}_{-} \mathrm{TiB}_{2} / \mathrm{Ti} 64$. a, b: the location of TiB2 particles; c-f: the locations of TiC particles, Figure S4. Engineering strength-Strain curves, Figure S5. (a) The content changes of $\mathrm{Al}$ and $\mathrm{V}$ element in $\beta$-Ti during solidification. (b) The content changes of $\mathrm{Al}$ and $\mathrm{V}$ element in $\beta$-Ti when 
the temperature is below the phase transform point, Figure S6. The statistical results of the size of $\alpha$-Ti colony, Table S1. Details of the tensile tests performed on the cast Ti64 and TiC-TiB $2 / \mathrm{Ti}_{6} 4$ after heat treatment.

Author Contributions: Conceptualization, Supervision, Project Administration, Funding Acquisition, Q.Z. and Q.J.; Methodology, Formal Analysis, Writing-Original Draft Preparation, Y.Z. and Q.Z.; Data Curation, Y.Z.; Investigation, Y.Z., X.L. and R.G.; Writing-Review \& Editing, Q.Z. and Q.J.; Software, B.W. All authors have read and agreed to the published version of the manuscript.

Funding: This work was funded by the National Natural Science Foundation of China, grant No. 51790483.

Conflicts of Interest: We declare no conflict of interest.

\section{References}

1. Rugg, D.; Britton, T.B.; Gong, J.; Wilkinson, A.J.; Bagot, P.A.J. In-service materials support for safety critical applications-A case study of a high strength Ti-alloy using advanced experimental and modelling techniques. Mater. Sci. Eng. A 2014, 599, 166-173. [CrossRef]

2. Duraiselvam, M.; Valarmathi, A.; Shariff, S.M.; Padmanabham, G. Laser surface nitrided Ti-6Al-4V for light weight automobile disk brake rotor application. Wear 2014, 309, 269-274. [CrossRef]

3. De Almeida, L.H.; Bastos, I.N.; Santos, I.D.; Dutra, A.J.B.; Nunes, C.A.; Gabriel, S.B. Corrosion resistance of aged Ti-Mo-Nb alloys for biomedical applications. J. Alloys Compd. 2015, 615, S666-S669. [CrossRef]

4. Banerjee, D.; Williams, J.C. Perspectives on titanium science and technology. Acta Mater. 2013, 61, 844-879. [CrossRef]

5. Ding, R.; Guo, Z.X.; Wilson, A. Microstructural evolution of a Ti-6Al-4V alloy during thermomechanical processing. Mater. Sci. Eng. A 2002, 327, 233-245. [CrossRef]

6. Lu, X.; Pan, Y.; Li, W.; Hayat, M.D.; Yang, F.; Singh, H.; Song, W.; Qu, X.; Xu, Y.; Cao, P. High-performance Ti composites reinforced with in-situ TiC derived from pyrolysis of polycarbosilane. Mater. Sci. Eng. A 2020, 795, 139924. [CrossRef]

7. Kim, Y.J.; Chung, H.; Kang, S.J.L. Processing and mechanical properties of Ti-6Al-4V/TiC in situ composite fabricated by gas-solid reaction. Mater. Sci. Eng. A 2002, 333, 343-350. [CrossRef]

8. Chen, R.; Tan, C.; Yu, X.; Hui, S.; Ye, W.; Lee, Y. Effect of TiB particles on the beta recrystallization behavior of the Ti-2Al-9.2Mo-2Fe-0.1B metastable beta titanium alloy. Mater. Charact. 2019, 153, 24-33. [CrossRef]

9. Sivakumar, G.; Ananthi, V.; Ramanathan, S. Production and mechanical properties of nano SiC particle reinforced Ti-6Al-4V matrix composite. Trans. Nonferr. Met. Soc. China 2017, 27, 82-90. [CrossRef]

10. Poletti, C.; Balog, M.; Schubert, T.; Liedtke, V.; Edtmaier, C. Production of titanium matrix composites reinforced with SiC particles. Compos. Sci. Technol. 2008, 68, 2171-2177. [CrossRef]

11. Qiu, D.; Zhang, D.; Easton, M.A.; St John, D.H.; Gibson, M.A. Refining As-cast $\beta$-Ti Grains through ZrN Inoculation. Metall. Mater. Trans. A Phys. Metall. Mater. Sci. 2018, 49, 1444-1449. [CrossRef]

12. Cui, Z.D.; Zhu, S.L.; Man, H.C.; Yang, X.J. Microstructure and wear performance of gradient Ti/TiN metal matrix composite coating synthesized using a gas nitriding technology. Surf. Coat. Technol. 2005, 190, 309-313. [CrossRef]

13. Feng, H.; Zhou, Y.; Jia, D.; Meng, Q. Microstructure and mechanical properties of in situ TiB reinforced titanium matrix composites based on Ti-FeMo-B prepared by spark plasma sintering. Compos. Sci. Technol. 2004, 64, 2495-2500. [CrossRef]

14. Rhee, S.I.; Nam, S.W.; Hagiwara, M. Effect of TiBp particle reinforcement on the creep resistance of near $\alpha$ titanium alloy made by blended elemental powder metallurgy. J. Alloys Compd. 2003, 359, 186-192. [CrossRef]

15. Ma, F.; Zhou, J.; Liu, P.; Li, W.; Liu, X.; Pan, D.; Lu, W.; Zhang, D.; Wu, L.; Wei, X. Strengthening effects of TiC particles and microstructure refinement in in situ TiC-reinforced Ti matrix composites. Mater. Charact. 2017, 127, 27-34. [CrossRef]

16. Ivasishin, O.M.; Markovsky, P.E.; Savvakin, D.G.; Stasiuk, O.O.; Rad, M.N.; Prikhodko, S.V. Multi-layered structures of Ti-6Al-4V alloy and $\mathrm{TiC}$ and $\mathrm{TiB}$ composites on its base fabricated using blended elemental powder metallurgy. J. Mater. Process. Technol. 2019, 269, 172-181. [CrossRef]

17. Feng, H.; Jia, D.; Zhou, Y. Spark plasma sintering reaction synthesized TiB reinforced titanium matrix composites. Compos. Part A Appl. Sci. Manuf. 2005, 36, 558-563. [CrossRef] 
18. Li, S.; Sun, B.; Imai, H.; Kondoh, K. Powder metallurgy Ti-TiC metal matrix composites prepared by in situ reactive processing of Ti-VGCFs system. Carbon 2013, 61, 216-228. [CrossRef]

19. Rahoma, H.K.S.; Chen, Y.Y.; Wang, X.P.; Xiao, S.L. Influence of (TiC + TiB) on the microstructure and tensile properties of Ti-B20 matrix alloy. J. Alloys Compd. 2015, 627, 415-422. [CrossRef]

20. Choi, B.J.; Kim, I.Y.; Lee, Y.Z.; Kim, Y.J. Microstructure and friction/wear behavior of $(\mathrm{TiB}+\mathrm{TiC})$ particulate-reinforced titanium matrix composites. Wear 2014, 318, 68-77. [CrossRef]

21. Hu, Z.Y.; Cheng, X.W.; Li, S.L.; Zhang, H.M.; Wang, H.; Zhang, Z.H.; Wang, F.C. Investigation on the microstructure, room and high temperature mechanical behaviors and strengthening mechanisms of the (TiB+TiC)/TC4 composites. J. Alloys Compd. 2017, 726, 240-253. [CrossRef]

22. Patil, A.S.; Hiwarkar, V.D.; Verma, P.K.; Khatirkar, R.K. Effect of $\mathrm{TiB}_{2}$ addition on the microstructure and wear resistance of Ti-6Al-4V alloy fabricated through direct metal laser sintering (DMLS). J. Alloys Compd. 2019, 777, 165-173. [CrossRef]

23. Handtrack, D.; Despang, F.; Sauer, C.; Kieback, B.; Reinfried, N.; Grin, Y. Fabrication of ultra-fine grained and dispersion-strengthened titanium materials by spark plasma sintering. Mater. Sci. Eng. A 2006, 437, 423-429. [CrossRef]

24. Bermingham, M.J.; Kent, D.; Zhan, H.; Stjohn, D.H.; Dargusch, M.S. ScienceDirect Controlling the microstructure and properties of wire arc additive manufactured Ti-6Al-4V with trace boron additions. Acta Mater. 2015, 91, 289-303. [CrossRef]

25. Gu, D.; Wang, H.; Zhang, G. Selective laser melting additive manufacturing of Ti-based nanocomposites: The role of nanopowder. Metall. Mater. Trans. A Phys. Metall. Mater. Sci. 2014, 45, 464-476. [CrossRef]

26. Martin, J.H.; Yahata, B.D.; Hundley, J.M.; Mayer, J.A.; Schaedler, T.A.; Pollock, T.M. 3D printing of high-strength aluminium alloys. Nature 2017, 549, 365-369. [CrossRef] [PubMed]

27. Du, Z.X.; Xiao, S.L.; Wang, P.X.; Xu, L.J.; Chen, Y.Y.; Rahoma, H.K.S. Effects of trace TiB and TiC on microstructure and tensile properties of $\beta$ titanium alloy. Mater. Sci. Eng. A 2014, 596, 71-79. [CrossRef]

28. Gao, Y.Y.; Dong, B.X.; Qiu, F.; Geng, R.; Wang, L.; Zhao, Q.L.; Jiang, Q.C. The superior elevated-temperature mechanical properties of Al-Cu-Mg-Si composites reinforced with in situ hybrid-sized $\mathrm{TiCx}^{-\mathrm{TiB}_{2}}$ particles. Mater. Sci. Eng. A 2018, 728, 157-164. [CrossRef]

29. Okamoto, H. Supplemental Literature Review of Binary Phase Diagrams: B-La, B-Zn, Bi-La, Bi-Ti, Cd-Pr, Ce-Ga, Cu-Na, Ge-Ta, Ge-Y, H-Zr, Na-Si, and Pb-Sc. J. Phase Equilib. Diffus. 2015, 36, 644-655. [CrossRef]

30. Cherukuri, B.; Srinivasan, R.; Tamirisakandala, S.; Miracle, D.B. The influence of trace boron addition on grain growth kinetics of the beta phase in the beta titanium alloy Ti-15Mo-2.6Nb-3Al-0.2Si. Scr. Mater. 2009, 60, 496-499. [CrossRef]

31. Gil, F.J.; Ginebra, M.P.; Manero, J.M.; Planell, J.A. Formation of $\alpha$-Widmanstätten structure: Effects of grain size and cooling rate on the Widmanstätten morphologies and on the mechanical properties in Ti6Al4V alloy. J. Alloys Compd. 2001, 329, 142-152. [CrossRef]

32. Lee, E. Microstructure Evolution and Microstructure/Mechanical Properties Relationships in $\alpha+\beta$ Titanium Alloys. Ph.D. Thesis, The Ohio State University, Columbus, OH, USA, 2004.

33. Roy, S.; Suwas, S.; Tamirisakandala, S.; Miracle, D.B.; Srinivasan, R. Development of solidification microstructure in boron-modified alloy Ti-6Al-4V-0.1B. Acta Mater. 2011, 59, 5494-5510. [CrossRef]

34. Chen, Z.Q.; Hu, D.; Loretto, M.H.; Wu, X. Effect of carbon additions on microstructure and mechanical properties of Ti-15-3. Mater. Sci. Technol. 2004, 20, 343-349. [CrossRef]

35. Lütjering, G. Influence of processing on microstructure and mechanical properties of $(\alpha+\beta)$ titanium alloys. Mater. Sci. Eng. A 1998, 243, 32-45. [CrossRef]

36. Semiatin, S.L.; Bieler, T.R. The effect of alpha platelet thickness on plastic flow during hot working of Ti-6Al-4V with a transformed microstructure. Acta Mater. 2001, 49, 3565-3573. [CrossRef]

37. Sen, I.; Tamirisakandala, S.; Miracle, D.B.; Ramamurty, U. Microstructural effects on the mechanical behavior of B-modified Ti-6Al-4V alloys. Acta Mater. 2007, 55, 4983-4993. [CrossRef]

38. Zhang, C.J.; Guo, C.X.; Zhang, S.Z.; Feng, H.; Chen, C.Y.; Zhang, H.Z.; Cao, P. Microstructural manipulation and improved mechanical properties of a near $\alpha$ titanium alloy. Mater. Sci. Eng. A 2020, 771, 138569. [CrossRef]

39. Jiang, L.; Wen, H.; Yang, H.; Hu, T.; Topping, T.; Zhang, D.; Lavernia, E.J.; Schoenung, J.M. Influence of length-scales on spatial distribution and interfacial characteristics of $\mathrm{B} 4 \mathrm{C}$ in a nanostructured $\mathrm{Al}$ matrix. Acta Mater. 2015, 89, 327-343. [CrossRef] 
40. Lin, J.; Cheong, B.H.; Yao, X. Universal multi-objective function for optimising superplastic-damage constitutive equations. J. Mater. Process. Technol. 2002, 125-126, 199-205. [CrossRef]

41. Babu, B.; Lindgren, L.E. Dislocation density based model for plastic deformation and globularization of Ti-6Al-4V. Int. J. Plast. 2013, 50, 94-108. [CrossRef]

42. Brandes, E.A.; Brook, G.B. Smithells Light Metals Handbook; Butterworth-Heinemann: Oxford, UK, 1998; ISBN 978-0-7506-3625-4.

Publisher's Note: MDPI stays neutral with regard to jurisdictional claims in published maps and institutional affiliations.

(C) 2020 by the authors. Licensee MDPI, Basel, Switzerland. This article is an open access article distributed under the terms and conditions of the Creative Commons Attribution (CC BY) license (http://creativecommons.org/licenses/by/4.0/). 